\title{
Application of Interactive Multimedia-Based Mathematics Learning Media to Increase Students' Interest in Learning
}

\author{
Dwianti Putri Amelia ${ }^{1}$, Amin Harahap ${ }^{2}$ \\ ${ }^{1,2}$ Faculty of Teacher Training and Education, Universitas Labuhanbatu, Indonesia \\ dwiantiputriamelia12@gmail.com,aminharahap19@gmail.com
}

\begin{abstract}
This study aims to overcome students' low interest in learning mathematics by using interactive multimedia learning models to increase students' interest in learning mathematics in class VII MTS PP ATH-TOHIRIYAH Gunung Selamat in the midst of the Corona Virus outbreak. With the application of this interactive multimedia learning model, it is hoped that it will increase students' interest in learning mathematics. The research method used in this study is a quantitative method with a class action method. In this study, the authors analyzed the data from the pretest and post-test scores from both classes. The population in this study were all students of MTS PP ATH-TOHIRIYAH Gunung Selamat grade VII, totaling 40 students. The sampling technique used is probability sampling using cluster sampling. From the results of data analysis, it is known that there is a difference between the average value of student learning outcomes before and after the implementation where the average value of the experimental pre-test is $56.60 \%$ and the control pre-test is $66.70 \%$ and becomes $86.55 \%$ for the experimental post-test and $75.30 \%$ for the control post-test. The experimental class increased by $29.95 \%$, while the control class only increased by $8.60 \%$. Based on the results of research and data processing that have been discussed, it can be concluded that the application of the interactive multimedia-based mathematics learning process has an impact on student learning interest in terms of student learning outcomes.
\end{abstract}

Keywords

learning process; mathematics; interactive multimedia

\section{Introduction}

Mathematics is a subject in a structured, i.e. in study that we first understand the material that is easiest to material hardest (Sakiah and Effendi 2021). Mathematics lessons that are useful in everyday life this is a subject that still feared learners (Handayani et al 2020). Mathematics is a science of using reason so that mathematics is considered to be something that is difficult to learn. There are many students who can not reach the Minimum Completeness Criteria associated with mathematics. Many things that become the cause of low mathematics learning outcomes of students, one of the learning media used by the teacher

Corona Virus Disease (Covid-19) is a virus that appeared in Wuhan, China in the sixth year of 2019. The outbreak of Corona virus (Covid-19) continued to take casualties around the world. Based on the data obtained (21/01) recorded 951.651 positive patients with Covid-19 in Indonesia (Kemenkes RI, 2021). The world of education is also affected by the outbreak of Covid-19. One of the effects of the pandemic Corona virus, namely to education around the world, which leads to the closure of schools, madrassas, universities, and boarding schools (Conscience et al., 2020). Indonesia became one of the country are also closing schools and all schools in all levels of education. The government appealed to 
all the people of Indonesia to work, study and worship from home during the pandemic Covid-19, even the government also cancel the National Exam 2020. This is done by the government to suppress the spread of Covid-19 in Indonesia. The goddess (2020) said that on March 24, 2020 the Minister of Education and Culture Republic of Indonesia issued Circular No. 4 of the Year 2020 On the Implementation of Education Policy In the Period of the Emergency the Spread of Covid, in a Circular Letter explained that the learning process is carried out at home through online learning or distance learning is implemented to provide learning experiences that are meaningful for students.

According to Hasan (Annur \& Hermansyah, 2020) online learning or e-learning is one of learning models the latest in the world of education that is able to overcome the limitations of the space that has been the weakness of conventional learning models. Online learning is one of learning models that are made with the use of technology devices in the middle of the pandemic at this time (Mansyur, 2020). Online learning is an innovation in education to meet the challenges of the availability of learning resources are varied (the Goddess, 2020). However, not all educators are ready to apply the method of learning online. A number of difficulties encountered educators, educators still very unfamiliar with the methods of online learning and media used to support the learning process. Likewise with the learners, the learners difficulties in understanding the material and submitted when online learning, especially in mathematics, learning with classroom action Research can improve the learning outcomes (Harahap A 2016).

Sujanto (2004) in (Saleh and Malinta 2020) defines "interest as something the concentration that accident of being born with the full accord and depending on the talent and the environment". Slameto (2010) in (Janudin et al 2020) stated that "the interest as a tendency that the fixed to pay attention to the constantly accompanied by a sense of fun". From both of these definitions it can be said that interest in learning is an impulse that is owned by a student to pay attention to learning faced by voluntarily without any coercion as shown with a happy feeling and it happens continuously for learning that lasts.

But from the observations that have been carried out on the MTS PP ATHTOHIRIYAH Gunung Selamat, especially class VII shows that the learning interest of students towards mathematics decreases caused by the presence of learning online, where in the process the students can not ask directly for any problems encountered in the learning process and the learning time is very limited and to the provision of material is only done by the teacher gives the math book then notify the page that will be discussed to the students and then the students learn on their own. Therefore, the researcher aims to apply the process of learning math-based interactive multimedia to enhance the learning interest of the students.

Interactive Multimedia is a multimedia equipped with a controller that can be operated by the user, so the user can choose what you want for the next process (Faqih, Nurdiawan, and Setiawan 2021). Examples of interactive multimedia is an interactive learning game app. Media-based interactive learning multimedia is used to deliver the message (knowledge, skills and attitudes) and can stimulate an option, feelings, attention and willingness to students so deliberate process of learning occurs, aiming and control (Faqih et al. 2021).

Based on what has been presented above, this study aims to address low learning interest of the students towards mathematics lesson using the learning model of interactive multimedia to improve the interest in learning mathematics of students in class VII MTS PP ATH-TOHIRIYAH Gunung Selamat amid the spread of the Corona Virus that causes students can't do the learning activities directly in the school environment. With the application of the learning model of interactive multimedia is expected to increase the 
interest belajra students to the subjects of mathematics, so that students can formulate, interpret and apply mathematics in a variety of contexts, especially in everyday life (Hidayat, Junaidi, and Yakob 2020).

\section{Research Methods}

The research method used in this research is quantitative method with the method of the action class. Action research (action research) included in the scope of applied research (applied research) which combines between knowledge, research and action. Action research have in common with research: participatory research, collaborative inquiry, emancipatory research, action learning, and contextual action research. Put simply, action research is "learning by doing" that apply in the context of a person's job in this case students (Mulyatiningsih 2009) in the (Ipa 2020).

This study will look at the application of mathematics learning media based interactive multimedia to enhance the learning interest of the students based on the results of student learning. In the research of this author first design (planning) interactive multimedia which will be applied as well as designing questions and give you about such as the pre-test to both classes. Then the author gives about the post-test which has been added in interactive multimedia in the experimental class and the matter of post-test in the control class, after that, the researchers conducted an analysis of data the results of the pretest and post-test of the second class.

The population in this research is the selur-students/sisters OF THE ATHTOHIRIYAH Gunung Selamat EIGHTH class STUDENTS who have 40 students who are currently in control classes and experimental classes. Sampling techniques used as a sampling area with a sampling cluster (Sharma 2017). Instrument and data collection techniques used in this research is test form a multiple choice to measure students ' interest in mathematics lessons, and observations used to determine how students are understanding the lesson with the application of the method of interactive multimedia (Faqih et al. 2021). The data analysis technique used is quantitative descriptive with how to analyze the data with descriptive statistics such as Descriptive Analysis, Normality Test, Paired Sample T Test, Test of independent sample t test against the results of pre-test and post-test are then presented in form of tables, graphs (Isnawati, Jalinus, and Risfendra 2020).

\section{Results and Discussion}

This study aims to see the process of the application of mathematics learning-based interactive multimedia to enhance the learning interest of the students. This research is only running in one cycle because the cycle of the first researchers have obtained data that can show the difference of experiment and control class. To analyze the results of the success of the application of the process of mathematics learning-based interactive multimedia to enhance the learning interest of students can be seen from the changes of student learning outcomes in answer to a math problem, the level of understanding of the concept, and how to understand the lesson. Here is a description of the analysis of the application of the process of mathematics learning-based interactive multimedia to enhance the learning interest of the students. 


\section{The Analysis of Test Data}

To analyze the data were Pre-Test and Post-Test to students of MTS PP ATHTOHIRIYAH Mountain Congratulations Class VII. The Pre-Test and Post-Test given to students in the form of the test multiple choice which function to view the mathematical ability of students with test materials tailored to the level of education students. The data processing results of Pre-Test and Post-Test is performed using MS.Excel and SPSS (Ariskasari and Pratiwi 2019). Pre-Test given to the students before the application of the process of mathematics learning-based interactive multimedia and Post-Test given to students after the application of the process of mathematics learning-based interactive multimedia to enhance the learning interest of the students. The results of Pre-Test and Post-Test obtained is as follows:

\section{a. Descriptive Analysis}

This analysis aims to explain and describe research data in the form of the amount of data, minimum value, maximum value, average value. Here are the results of descriptive statistics:

Table 1. Descriptive Statistics

\begin{tabular}{|l|r|r|r|r|r|}
\hline & \multicolumn{1}{|c|}{ N } & Minimum & Maximum & Mean & Std. Deviation \\
\hline Pre-Test Eksperimen & 20 & 45 & 70 & 56.60 & 8.075 \\
Post-Test Eksperimen & 20 & 75 & 100 & 86.55 & 6.747 \\
Pre-Test Kontrol & 20 & 53 & 80 & 66.70 & 7.801 \\
Post-Test Kontrol & 20 & 65 & 84 & 75.30 & 5.787 \\
Valid N (listwise) & 20 & & & & \\
\hline
\end{tabular}

Based on the above table it can be seen the difference between the average value of student learning outcomes before and after the implementation where the average value of pre-test experiment is $56.60 \%$ and the pre-test control is $66.70 \%$ and be $86.55 \%$ for posttest experimental and $75.30 \%$ for post-test control. On the class of the experiment increased by $29.95 \%$, while for the control class only increased by $8.60 \%$.

\section{Normality Test}

Testing the normality test of the data was conducted to determine whether the normal distribution of data that is an absolute requirement for testing the analysis of parametric (paired sample $t$ test and independent sample $t$ test), if the data is not normal it will be done the Wilcoxon test and Mann Whitney test(Pharisees, Hamid, and Melvina 2017). The results of the test of normality following:

Table 2. Tests of Normality

\begin{tabular}{|l|r|r|r|r|r|r|r|}
\hline & \multirow{2}{*}{} & Kelas & \multicolumn{3}{|c|}{ Kolmogorov-Smirnov } & \multicolumn{3}{|c|}{ Shapiro-Wilk } \\
\cline { 2 - 8 } & Statistic & \multicolumn{1}{c|}{ df } & \multicolumn{1}{c|}{ Sig. } & Statistic & df & \multicolumn{1}{c|}{ Sig. } \\
\hline Student Learning Pre-Test & .156 & 20 & $.200^{*}$ & .931 & 20 & .163 \\
Outcomes & & & & & & \\
& Eksperimen & .077 & 20 & $.200^{*}$ & .982 & 20 & .954 \\
& Post-Test & & & & \\
& Eksperimen & & & & & \\
& Pre-Test Kontrol & .115 & 20 & $.200^{*}$ & .960 & 20 & .536 \\
& Post-Test Kontrol & .092 & 20 & $.200^{*}$ & .959 & 20 & .514 \\
\hline
\end{tabular}

*. This is a lower bound of the true significance.

a. Lilliefors Significance Correction 
Based on the results of the test nomalitas can be seen that the data berdistriusi normal seen from the value of Sig < 0.05, both on the test Kolmogoro-Sminorv (Nahdi 2018) and Shapiro-Wilk (Suyana, Ati, and Widiyarto 2019). Thus, it can be done the test and paired sample $\mathrm{t}$ test against :

\section{Paired Test T Sample Uji}

This test aims to see the effect of the application of mathematics learning media based interactive multimedia to enhance the learning interest of the students. Following the results of the data analysis:

Table 3. Paired Samples Test

Paired Samples Test

\begin{tabular}{|c|c|c|c|c|c|c|c|c|c|}
\hline & \multicolumn{5}{|c|}{ Paired Differences } & \multirow[b]{3}{*}{$\mathrm{t}$} & \multirow[b]{3}{*}{$\mathrm{df}$} & \multirow{3}{*}{$\begin{array}{l}\text { Sig. (2- } \\
\text { tailed) }\end{array}$} \\
\hline & & \multirow[b]{2}{*}{ Mean } & \multirow{2}{*}{$\begin{array}{c}\text { Std. } \\
\text { Deviation }\end{array}$} & \multirow{2}{*}{$\begin{array}{l}\text { Std. } \\
\text { Error } \\
\text { Mean }\end{array}$} & \multicolumn{2}{|c|}{$\begin{array}{l}\text { 95\% Confidence } \\
\text { Interval of the } \\
\text { Difference } \\
\end{array}$} & & & \\
\hline & & & & & Lower & Upper & & & \\
\hline $\begin{array}{l}\text { Pair } \\
1\end{array}$ & $\begin{array}{l}\text { Pre-Test } \\
\text { Eksperimen - } \\
\text { Post-Test } \\
\text { Eksperimen }\end{array}$ & 29.950 & 11.980 & 2.679 & -35.557 & -24.343 & 11.180 & 19 & .000 \\
\hline $\begin{array}{l}\text { Pair } \\
2\end{array}$ & $\begin{array}{l}\text { Pre-Test } \\
\text { Kontrol - Post- } \\
\text { Test Kontrol }\end{array}$ & -8.600 & 6.159 & 1.377 & -11.483 & -5.717 & -6.244 & 19 & .000 \\
\hline
\end{tabular}

From the results of the analysis are known to the implementation of mathematics learning media based interactive multimedia to enhance the learning interest of students seen from the value of Sig. $0.000<0.05$ (Sultoni, Gunawan, and Pratiwi 2018) where average effect of the application of mathematics learning media based interactive multimedia to enhance the learning interest of students $29.95 \%$ and conventional by $8.60 \%$.

\section{Test Homogenitas}

This analysis aims to look at the variant data Pre-Test and Post-Test of experimental class and the control class is the same or HOMOGENEOUS (Wiliawanto et al. 2019). Following the results of the data analysis :

Table 4. Test of Homogeneity of Variance

\begin{tabular}{|ll|r|r|r|r|}
\hline & & \multicolumn{1}{c|}{$\begin{array}{c}\text { Levene } \\
\text { Statistic }\end{array}$} & \multicolumn{1}{c|}{ df1 } & \multicolumn{1}{c|}{ df2 } & \multicolumn{1}{c|}{ Sig. } \\
\hline Hasil Post-Test & Based on Mean & .212 & 1 & 38 & .648 \\
Belajar & Based on Median & .170 & 1 & 38 & .683 \\
& Based on Median and & .170 & 1 & 34.702 & .683 \\
& with adjusted df & .222 & 1 & 38 & .640 \\
& Based on trimmed mean & & & \\
\hline
\end{tabular}


Based on the results of the Pre-Test and Post-Test of experimental class and the control class is the same or HOMOGENEOUS seen from the value of Sig. Based on the Mean of $0.648>0.05$, thus one of the requirements (not absolute) of the Test independent sample $\mathrm{t}$ test are met (Pharisees et al. Two thousand seventeen).

\section{Independent Sample T Test}

This analysis aims to look at the differences in learning outcomes of students on the implementation of mathematics learning media based interactive multimedia to enhance the learning interest of the students (Ultimate, Subali, and Linuwih 2017) Blended Learning and conventional. Following the results of the data analysis :

Table 5. Independent Samples Test

\begin{tabular}{|c|c|c|c|c|c|c|c|c|c|c|}
\hline & \multicolumn{2}{|c|}{$\begin{array}{c}\text { Levene's } \\
\text { Test for } \\
\text { Equality } \\
\text { of } \\
\text { Variances }\end{array}$} & \multicolumn{7}{|c|}{ t-test for Equality of Means } \\
\hline & & \multirow[b]{2}{*}{$\mathrm{F}$} & \multirow[b]{2}{*}{ Sig. } & \multirow[b]{2}{*}{$\mathrm{t}$} & \multirow[b]{2}{*}{$\mathrm{df}$} & \multirow{2}{*}{$\begin{array}{c}\text { Sig. } \\
(2- \\
\text { tailed })\end{array}$} & \multirow{2}{*}{$\begin{array}{c}\text { Mean } \\
\text { Difference }\end{array}$} & \multirow{2}{*}{$\begin{array}{l}\text { Std. Error } \\
\text { Difference }\end{array}$} & \multicolumn{2}{|c|}{$\begin{array}{c}95 \% \\
\text { Confidence } \\
\text { Interval of the } \\
\text { Difference }\end{array}$} \\
\hline & & & & & & & & & Lower & Upper \\
\hline $\begin{array}{l}\text { Hasil } \\
\text { Post- } \\
\text { Test }\end{array}$ & $\begin{array}{l}\text { Equal } \\
\text { variances } \\
\text { assumed }\end{array}$ & .212 & .648 & 5.660 & 38 & .000 & 11.250 & 1.988 & 7.226 & 15.274 \\
\hline Belajar & $\begin{array}{l}\text { Equal } \\
\text { variances } \\
\text { not } \\
\text { assumed }\end{array}$ & & & 5.660 & 37.138 & .000 & 11.250 & 1.988 & 7.223 & 15.277 \\
\hline
\end{tabular}

Based on the results of the analysis it is known that the value of Sig.(2-tailed) 0.000 $<0.05$ (Ramadhani 2017), it can be concluded there is a difference in student learning outcomes between the experimental class and the control class of the implementation of mathematics learning media based interactive multimedia to enhance the learning interest of the students with the difference of $21.35 \%$.

\section{b. The Analysis Of The Observation}

Based on the observation that has been done in class VII MTS PP ATHTOHIRIYAH Mount Welcome, be aware that learning is not yet using interactive learning media. Therefore, researchers took the initiative to create an interactive learning media After the treatment is given to students that by applying mathematics learning media using adobe flash, seen from the learning outcomes of students increased so it can be said also that the interest of learning has increased. Based on the results of observations made by the author to the character of student learning, the authors conclude that before the implementation of the process of mathematics learning-based interactive multimedia interest of students in learning is still relatively low, after the application of the process of mathematics learning-based interactive multimedia students are more active due to the use of the media that is interactive. 


\section{Conclusion}

Based on the results of research and data processing that have been discussed can be concluded that the application of the process of mathematics learning-based interactive multimedia has an impact on the interest of student learning review of student learning outcomes. In addition it is known that the large influence of the process of mathematics learning-based interactive multimedia on the value of mathematics students by $29.95 \%$, so it can be concluded that the influence of, and differences in learning outcomes of students on the process of learning math-based interactive multimedia to enhance the learning interest of the students. So the application of the process of mathematics learning-based interactive multimedia can be used for so on in increasing the interest and increase the value of student learning, especially in the subjects mathematics.

\section{References}

Alan, Usman Fauzan, and Ekasatya Aldila Afriansyah. 2017. "Kemampuan Pemahaman Matematis Siswa Melalui Model Pembelajaran Auditory Intellectualy Repetition Dan Problem Based Learning." Jurnal Pendidikan Matematika 11(1). doi: 10.22342/jpm.11.1.3890.67-78.

Ariskasari, Dewi, and Dona Dinda Pratiwi. 2019. "Pengembangan Modul Matematika Berbasis Problem Solving Pada Materi Vektor." Desimal: Jurnal Matematika 2(3):249-58. doi: 10.24042/djm.v2i3.4454.

Belajar, Minat. 2020. "Delta-Pi: Jurnal Matematika Dan Pendidikan Matematika Vol. 9 No. 2, 2020." 9(2):120-31.

Faqih, Ahmad, Odi Nurdiawan, and Andi Setiawan. 2021. "Pengembangan Media Pembelajaran Multimedia Interaktif Alat Masak Tradisional Berbasis Etnomatematika." 10:301-10.

Farisi, Ahmad, Abdul Hamid, and Melvina. 2017. "Pengaruh Model Pembelajaran Problem Based Learning Terhadap Kemampuan Berpikir Kritis Dalam Meningkatkan Hasil Belajar Ssiswa Pada Konsep Suhu Dan Kalor.” Jurnal Ilmiah Mahasiswa 2(3):283-87.

Harahap, amin. 2016. Upaya Meningkatkan Hasil Belajar Matematika Siswa Melalui Metode Investigasi Kelompok Pada Materi Kubus Dan Balok Di Kelas Viii Mts Ibrahimy Rantauprapat. Sigma. Vol.2, no.1 mei 2016 hal $1-3$

Hidayat, Muhammad Taufik, Teuku Junaidi, and Muhammad Yakob. 2020. "Pengembangan Model Pembelajaran Blended Learning Dalam Meningkatkan Pemahaman Siswa Terhadap Tradisi Lisan Aceh.” 25(3):401-10.

Ipa, Mata Pelajaran. 2020. "Dapat Meningkatkan Hasil Belajar Siswa Tentang Hubungan Antara Makluk Hidup Di Kelas IV Semester I SD Negeri Karang Asih 12 Tahun Pelajaran 2017/2018?." 8(4):25-33.

Isnawati, Isnawati, Niswardi Jalinus, and Risfendra Risfendra. 2020. "Analisis Kemampuan Pedagogi Guru SMK Yang Sedang Mengambil Pendidikan Profesi Guru Dengan Metode Deskriptif Kuantitatif Dan Metode Kualitatif.” INVOTEK: Jurnal Inovasi Vokasional Dan Teknologi 20(1):37-44. doi: 10.24036/invotek.v20i1.652.

Matematika, Jurnal Pendidikan, Materi Barisan, and D. A. N. Deret. 2020. " $\pi$ ( Phi )." 4(2017):160-68.

Mudik, Kecamatan Kuantan. 2020. "Kata Kunci: Ekstrakurikuler Panahan, Konsentrasi Belajar." 185-92. 
Mulyatiningsih, Endang. 2009. "Modul Pelatihan Pendidikan Profesi Guru Fakultas Teknik Universitas Negri Yogyakarta." Bandung Rosdakarya 1-22.

Nahdi, Dede Salim. 2018. "Eksperimentasi Model Problem Based Learning Dan Model Guided Discovery Learning Terhadap Kemampuan Pemecahan Masalah Matematis Ditinjau Dari Self Efficacy Siswa." Jurnal Cakrawala Pendas 4(1). doi: 10.31949/jcp.v4i1.711.

Ningsih, Yunika Lestaria, Misdalina Misdalina, and Marhamah Marhamah. 2017. "Peningkatan Hasil Belajar Dan Kemandirian Belajar Metode Statistika Melalui Pembelajaran Blended Learning." Al-Jabar : Jurnal Pendidikan Matematika 8(2):155. doi: 10.24042/ajpm.v8i2.1633.

Pamungkas, Aji, Bambang Subali, and Suharto Linuwih. 2017. "Implementasi Model Pembelajaran IPA Berbasis Kearifan Lokal Untuk Meningkatkan Kreativitas Dan Hasil Belajar Siswa." Jurnal Inovasi Pendidikan IPA 3(2):118. doi: 10.21831/jipi.v3i2.14562.

Ramadhani, Hetti Sari. 2017. "Hetti Sari Ramadhani.” Persona: Jurnal Psikologi Indonesia 6(2):66-74.

Sakiah, Nur Afifatus, and Kiki Nia Sania Effendi. 2021. "Analisis Kebutuhan Multimedia Interaktif Berbasis PowerPoint Materi Aljabar Pada Pembelajaran Matematika SMP.” JP3M (Jurnal Penelitian Pendidikan Dan Pengajaran Matematika) 7(1):39-48. doi: 10.37058/jp3m.v7i1.2623.

Saleh, M. Sahib, and Sunandar Sakria Malinta. 2020. "Survei Minat Belajar Siswa Dalam Mengikuti Pembelajaran Pendidikan Jasmani Di Smpn 30 Makassar." Kinestetik 4(1):55-62. doi: 10.33369/jk.v4i1.10347.

Sharma, Gaganpreet. 2017. "Pros and Cons of Different Sampling Techniques." International Journal of Applied Research 3(7):749-52.

Sultoni, Imam Gunawan, and Firda Dwi Pratiwi. 2018. "Perbedaan Motivasi Belajar Mahasiswa Antara Sebelum." Ilmu Pendidikan: Jurnal Kajian Teori Dan Praktik Kependidikan 3(1):115-18.

Suyana, Nana, Aster Pujaning Ati, and Sigit Widiyarto. 2019. "Metode Partisipatori Untuk Meningkatkan Kemampuan Menulis Argumentasi Pada Siswa MTs Nurul Hikmah Kota Bekasi." Linguista: Jurnal Ilmiah Bahasa, Sastra, Dan Pembelajarannya 2(2):80. doi: 10.25273/linguista.v2i2.3702.

Wiliawanto, Windi, Martin Bernard, Padillah Akbar, and Asep Ikin Sugandi. 2019. "Penerapan Strategi Pembelajaran Aktif Question Student Have Untuk Meningkatkan Kemampuan Berpikir Kritis Matematik Siswa SMK." Jurnal Cendekia: Jurnal Pendidikan Matematika 3(1):139-48. doi: 10.31004/cendekia.v3i1.86.

Alan, Usman Fauzan, and Ekasatya Aldila Afriansyah. 2017. "Kemampuan Pemahaman Matematis Siswa Melalui Model Pembelajaran Auditory Intellectualy Repetition Dan Problem Based Learning." Jurnal Pendidikan Matematika 11(1). doi: 10.22342/jpm.11.1.3890.67-78.

Ariskasari, Dewi, and Dona Dinda Pratiwi. 2019. "Pengembangan Modul Matematika Berbasis Problem Solving Pada Materi Vektor." Desimal: Jurnal Matematika 2(3):249-58. doi: 10.24042/djm.v2i3.4454.

Belajar, Minat. 2020. "Delta-Pi: Jurnal Matematika Dan Pendidikan Matematika Vol. 9 No. 2, 2020." 9(2):120-31.

Faqih, Ahmad, Odi Nurdiawan, and Andi Setiawan. 2021. "Pengembangan Media Pembelajaran Multimedia Interaktif Alat Masak Tradisional Berbasis Etnomatematika." 10:301-10. 
Farisi, Ahmad, Abdul Hamid, and Melvina. 2017. "Pengaruh Model Pembelajaran Problem Based Learning Terhadap Kemampuan Berpikir Kritis Dalam Meningkatkan Hasil Belajar Ssiswa Pada Konsep Suhu Dan Kalor.” Jurnal Ilmiah Mahasiswa 2(3):283-87.

Hidayat, Muhammad Taufik, Teuku Junaidi, and Muhammad Yakob. 2020. "Pengembangan Model Pembelajaran Blended Learning Dalam Meningkatkan Pemahaman Siswa Terhadap Tradisi Lisan Aceh." 25(3):401-10.

Ipa, Mata Pelajaran. 2020. "Dapat Meningkatkan Hasil Belajar Siswa Tentang Hubungan Antara Makluk Hidup Di Kelas IV Semester I SD Negeri Karang Asih 12 Tahun Pelajaran 2017/2018?." 8(4):25-33.

Isnawati, Isnawati, Niswardi Jalinus, and Risfendra Risfendra. 2020. "Analisis Kemampuan Pedagogi Guru SMK Yang Sedang Mengambil Pendidikan Profesi Guru Dengan Metode Deskriptif Kuantitatif Dan Metode Kualitatif." INVOTEK: Jurnal Inovasi Vokasional Dan Teknologi 20(1):37-44. doi: 10.24036/invotek.v20i1.652.

Sakiah, Nur Afifatus, and Kiki Nia Sania Effendi. 2021. "Analisis Kebutuhan Multimedia Interaktif Berbasis PowerPoint Materi Aljabar Pada Pembelajaran Matematika SMP.” JP3M (Jurnal Penelitian Pendidikan Dan Pengajaran Matematika) 7(1):39-48. doi: 10.37058/jp3m.v7i1.2623.

Saleh, M. Sahib, and Sunandar Sakria Malinta. 2020. "Survei Minat Belajar Siswa Dalam Mengikuti Pembelajaran Pendidikan Jasmani Di Smpn 30 Makassar." Kinestetik 4(1):55-62. doi: 10.33369/jk.v4i1.10347.

Sharma, Gaganpreet. 2017. "Pros and Cons of Different Sampling Techniques." International Journal of Applied Research 3(7):749-52.

Sultoni, Imam Gunawan, and Firda Dwi Pratiwi. 2018. "Perbedaan Motivasi Belajar Mahasiswa Antara Sebelum." Ilmu Pendidikan: Jurnal Kajian Teori Dan Praktik Kependidikan 3(1):115-18.

Suyana, Nana, Aster Pujaning Ati, and Sigit Widiyarto. 2019. "Metode Partisipatori Untuk Meningkatkan Kemampuan Menulis Argumentasi Pada Siswa MTs Nurul Hikmah Kota Bekasi." Linguista: Jurnal Ilmiah Bahasa, Sastra, Dan Pembelajarannya 2(2):80. doi: 10.25273/linguista.v2i2.3702. 